\title{
The acute respiratory distress syndrome in catastrophic antiphospholipid syndrome: analysis of a series of 47 patients
}

\author{
S Bucciarelli, G Espinosa, R A Asherson, R Cervera, G Claver, J A Gómez-Puerta, \\ M Ramos-Casals, M Ingelmo, J Font for the Catastrophic Antiphospholipid Syndrome \\ Registry Project Group*
}

Background: The acute respiratory distress syndrome (ARDS) is a non-cardiogenic form of pulmonary oedema characterised by severe hypoxaemia refractory to oxygen therapy, with diffuse pulmonary infiltrates on chest radiographs. It can be precipitated by various serious medical and surgical conditions, including systemic autoimmune diseases. The "catastrophic" variant of the antiphospholipid syndrome (APS) is an accelerated form of this systemic autoimmune condition which results in multiorgan failure because of multiple small vessel occlusions.

See end of article for authors' affiliations

Objective: To analyse the clinical and laboratory characteristics of patients with catastrophic APS who develop ARDS.

Correspondence to: Dr Ricard Cervera, Servei de Malalties Autoimmunes, Hospital Clínic, Villarroel 170, 08036, Barcelona, Catalonia, Spain rcervera@clinic.ub.es

Methods: Cases with ARDS were selected from the web site based international registry of patients with catastrophic APS (CAPS registry) (http://www.med.ub.es/MIMMUN/FORUM/CAPS.HTM) and their characteristics examined.

Results: Pulmonary involvement was reported in 150 of 220 patients with catastrophic APS (68\%) and 47 patients $(21 \%)$ were diagnosed as having ARDS. Nineteen $(40 \%)$ of these patients died. Pathological studies were undertaken in 10 patients and thrombotic microangiopathy was present in seven. There were no differences in age, sex, precipitating factors, clinical manifestations, or mortality between catastrophic APS patients with and without ARDS.

Accepted 14 May 2005

Published Online First

Conclusions: ARDS is the dominant pulmonary manifestation of catastrophic APS. Thus the existence of ARDS 26 May 2005

in the context of an APS makes it necessary to rule out the presence of the catastrophic variant of this syndrome.

$\mathrm{T}$ he acute respiratory distress syndrome (ARDS) is a noncardiogenic form of pulmonary oedema characterised by severe hypoxaemia refractory to oxygen therapy, with diffuse pulmonary infiltrates on chest radiographs. ${ }^{1}$ It can be precipitated by various serious medical and surgical conditions. ${ }^{2}$ Common causes include pneumonia, aspiration of gastric contents, sepsis, severe trauma with shock, and multiple transfusions. ${ }^{12}$ In the context of autoimmune diseases, several case reports have suggested that systemic lupus erythematosus (SLE) may be linked to ARDS..$^{3-7}$

In 1992, a new subset of the antiphospholipid syndrome (APS) was described, termed "catastrophic APS"8 or Asherson's syndrome, ${ }^{9}$ which has an acute and accelerated course. It is characterised by multiple vascular occlusive events, usually affecting small vessels, presenting over a short period of time, with laboratory confirmation of the presence of antiphospholipid antibodies (aPL). ${ }^{10}$ Several reviews have been published on a growing number of patients with this condition over the past few years. ${ }^{11-13}$ As more and more cases are documented, it has become obvious that there is an inordinately high frequency of pulmonary manifestations in the syndrome (particularly, ARDS), not seen with simple or "classic" APS.

Our objective in the present study was to analyse the clinical and laboratory characteristics of patients with catastrophic APS who develop ARDS.

\section{METHODS}

We analysed the web site based international registry of patients with catastrophic APS (the CAPS registry; http://

www.med.ub.es/MIMMUN/FORUM/CAPS.HTM) which, until February 2004 included 220 patients: 153 female and 67 male; mean (SD) age, 38 (14) years, range 7 to $74 ; 106$ with primary APS, 88 with SLE, 11 with lupus-like syndrome, and 15 with other diseases.

We selected those patients diagnosed by their physicians in charge as having ARDS (ratio of $\mathrm{PaO}_{2}$ to fraction of inspired oxygen $\left(\mathrm{FiO}_{2}\right)$ less than 200; evidence of bilateral infiltrates on chest radiographs; and no reason to suspect that the pulmonary oedema was cardiogenic). ${ }^{14}$ We included only cases with well documented clinical reports and fulfilling the classification criteria for catastrophic APS. Briefly, these criteria include evidence of involvement in three or more organs, systems, or tissues, development of manifestations simultaneously or in less than a week, confirmation by histopathology of small vessel occlusion in at least one organ or tissue, and laboratory confirmation of the presence of aPL. ${ }^{10}$

We summarised data from these patients using a standardised form, including sex, age, diagnosis of the underlying disorder, main clinical manifestations, immunological features, treatment, and outcome. To facilitate synthesis of the data, we categorised patients into three major diagnoses according to their underlying disease or syndrome:

- SLE if they met four or more of the American College of Rheumatology criteria ${ }^{16}$;

Abbreviations: aPL, antiphospholipid antibodies; APS, antiphospholipid syndrome; ARDS, acute respiratory distress syndrome; BALF, bronchoalveolar lavage fluid; SIRS, systemic inflammatory response syndrome 
- "lupus-like" syndrome if they met two or three American College of Rheumatology criteria;

- primary APS if they met criteria of the International Consensus Statement on preliminary classification for definite $\mathrm{APS}^{17}$ and did not meet the above criteria for SLE or lupus-like disease.

Fisher's exact test (bilateral) was employed for the statistical analysis, using the SPSS 10.0 statistical program.

\section{RESULTS}

\section{General characteristics}

Among the 220 patients included in the CAPS registry, pulmonary involvement was described in 150 patients $(68 \%)$, and data suggesting ARDS were reported in 56 (25\%). However, nine patients were excluded: three because of the presence of pneumonia as a cause of the ARDS, three because features of cardiac insufficiency were present, two because diffuse alveolar haemorrhage was revealed by biopsy, and one because necropsy revealed carcinoma of unknown origin. Thus 47 patients in all $(21 \%)$ were considered to have ARDS, representing nearly one third (31\%) of those having pulmonary involvement. The mean (SD) age of the patients with ARDS was 34 (16) years (range 9 to 74). Thirty six (77\%) were female, $22(47 \%)$ had SLE, 19 (40\%) had primary APS, and $5(11 \%)$ had lupus-like disease (in one case, this information was not available).

\section{Precipitating factors and clinical manifestations}

The general characteristics and precipitating factors of the catastrophic APS are summarised in table 1. In 17 patients (36\%), precipitating factors were not identified. The most striking precipitating factor, found in 15 patients (32\%), was infection, ranging from upper respiratory tract infections to gastrointestinal infections and other septic conditions such as urinary tract infection. Common causes of ARDS such as pneumonia or sepsis appeared to be precipitating factors of catastrophic APS in three patients. The second most frequent precipitating factor, found in six patients (13\%), was surgery and invasive procedures, ranging from an endoscopic retrograde cholangio-pancreatography to various major operations. Others were associated with drug treatment (11\%), obstetric complications (9\%), SLE flares (4\%), or withdrawal of anticoagulants $(2 \%)$.

Intra-abdominal involvement was identified in 42 patients (89\%), mainly consisting of renal $(81 \%)$, hepatic $(26 \%)$, gastrointestinal $(19 \%)$, pancreatic $(10 \%)$, adrenal $(17 \%)$, and splenic $(5 \%)$ manifestations. Thirty six patients $(77 \%)$ had evidence of cerebrovascular complications, mainly encephalopathy and cerebrovascular accidents, but occasionally seizures or transverse myelitis. Skin manifestations were also frequent (55\%) and consisted of livedo reticularis, ulcers, digital gangrene, purpura, and microthrombosis of small vessels. Twenty four patients $(51 \%)$ had cardiac involvement, mainly cardiac failure and confirmed myocardial infarction, Libman-Sacks non-bacterial endocarditis, or silent valve lesions. Peripheral venous thrombosis was present in 12 patients $(26 \%)$ and peripheral arterial occlusive disease in five $(11 \%)$.

Other abnormalities occasionally encountered were retinal, pleural, and peripheral nerve lesions.

There were no differences in age, sex, precipitating factors, or clinical manifestations between catastrophic APS patients with and without ARDS.

\section{Laboratory features}

The IgG isotype of anticardiolipin antibodies (aCL) was reported as positive in 38 patients $(81 \%)$ and the IgM aCL in
$16(34 \%)$. Lupus anticoagulant was present in 34 patients $(72 \%)$.

\section{Pathological features}

Histopathological study of lungs was undertaken in 10 patients (necropsy in eight, lung biopsy in two). The main finding was non-inflammatory thrombotic microangiopathy which was present in seven patients; intra-alveolar haemorrhage and hyaline membrane formation were each present in two cases. In all cases, pathological examination ruled out vasculitis.

\section{Treatment and outcome}

The treatment and outcome of the 47 patients with ARDS and catastrophic APS are shown in table 2. Data on treatment were not available for three patients. Finally, 44 episodes of ARDS were analysed. Anticoagulation was the most frequent treatment, used in 42 patients (95\%), followed by steroids in $39(89 \%)$. Immunosuppressants were used in 19 patients (43\%) (cyclophosphamide in 18 and vincristine in one), intravenous immunoglobulins were used in 21 patients $(48 \%)$, and plasma exchange in $15(34 \%)$. Intravenous prostaglandin was used in one case. Nineteen patients died $(40 \%)$. There was no statistically significant difference in mortality between catastrophic APS with ARDS and without ARDS. No differences were found in the recovery rate depending on the use or not of a particular treatment.

\section{DISCUSSION}

ARDS is associated with a variety of clinical disorders. These can be divided into two categories: those associated with direct injury to the lung, with direct effects on pulmonary cells (pneumonia, aspiration of gastric contents, pulmonary contusion, near drowning, and inhalational injury); and those that cause indirect lung injury in the setting of a systemic process through acute systemic inflammatory responses (sepsis, severe trauma with shock and multiple transfusions, cardiopulmonary bypass, drug overdose, and acute pancreatitis). ${ }^{18}$ Overall, sepsis is associated with the greatest risk of progression to ARDS (approximately 40\%). ${ }^{19}$ ARDS has also been documented in patients with SLE, ${ }^{3-7}$ which may be complicated by pulmonary hypertension, ${ }^{4}$ as well as in adult Still's disease. ${ }^{20}$ Its occurrence in catastrophic APS is a completely new association. In the present study, we found a frequency of $21 \%$ of ARDS in the patients with catastrophic APS.

Although alveolar haemorrhage may be responsible for dyspnoea in patients with catastrophic APS, it is infrequently encountered, probably because it is difficult to diagnose. ${ }^{22}$ Once other causes (such as cardiac failure, pneumonia, and recurrent pulmonary emboli) have been excluded clinically and by the appropriate investigations, ARDS is by far the commonest underlying pulmonary condition encountered.

An intriguing question is whether aPL may play a role in the development of ARDS in patients with catastrophic APS or, conversely, whether ARDS is produced by the same factor that precipitates the catastrophic APS - that is, infection or surgery. Although it is difficult to draw any firm conclusion because of the sparse data, several findings point towards a direct link between aPL and ARDS.

The first of these is that the acute phase of ARDS is characterised by an influx of protein-rich oedema fluid, with associated red cells and neutrophils, into the air spaces secondary to increased permeability of the alveolar-capillary barrier. ${ }^{23}$ This increase in endothelial and epithelial permeability allows higher molecular weight proteins, such as IgG and IgM, to enter the air spaces. ${ }^{24}$ Maneta-Peyret et al ${ }^{25}$ have reported an increased amount of IgG in the bronchoalveolar lavage fluid (BALF) of patients with ARDS in comparison 
Table 1 General characteristics of patients with acute respiratory distress syndrome plus catastrophic antiphospholipid syndrome

\begin{tabular}{|c|c|c|c|c|c|c|c|c|c|}
\hline Case $^{*}$ & Sex & $\begin{array}{l}\text { Age } \\
(y)\end{array}$ & Diagnosis & $\begin{array}{l}\text { Previous APS } \\
\text { manifestations }\end{array}$ & Precipitating factor & $\begin{array}{l}\text { Other organ involvement at the } \\
\text { time of catastrophic APS }\end{array}$ & LA & $\lg G$ aCl & $\operatorname{lgM}$ aCL \\
\hline $1(2)$ & M & 22 & Lupus-like & & & PVT, CNS, kidney, skin & + & + & + \\
\hline 2 (3) & $\mathrm{F}$ & 22 & Lupus-like & & & Heart, CNS, kidney, skin, retina & + & + & + \\
\hline 3 (14) & $\mathrm{F}$ & 11 & SLE & Epilepsy & Intestinal infection & CNS, skin, liver & + & - & - \\
\hline $4(16)$ & $\mathrm{F}$ & 23 & SLE & & ERCP & Heart, CNS, kidney, liver & + & Moderate + & - \\
\hline $5(20)$ & $\mathrm{F}$ & 43 & PAPS & DVT, fetal losses & & Heart, kidney, GI tract, adrenals & + & $276 \mathrm{GPL}$ & - \\
\hline $6(26)$ & M & 45 & SLE & $\begin{array}{l}\text { DVT, PE, SVC } \\
\text { thrombosis }\end{array}$ & & CNS, central retinal vein thrombi & - & 20 & - \\
\hline 7 (33) & $\mathrm{F}$ & 52 & Lupus-like & Fetal loss & Diuretic & $\begin{array}{l}\text { CNS, kidney, liver, GI tract, } \\
\text { pancreas }\end{array}$ & NR & High + & High + \\
\hline $8(36)$ & $\mathrm{F}$ & 36 & PAPS & DVT & & $\begin{array}{l}\text { Heart, kidney, Gl tract, adrenal } \\
\text { glands, thyroid, muscle, } \\
\text { peripheral nerves }\end{array}$ & + & $95 \mathrm{GPL}$ & - \\
\hline $9(41)$ & $\mathrm{F}$ & 35 & PAPS & $\begin{array}{l}\text { Fetal loss, PAT, } \\
\text { skin ulcers }\end{array}$ & & CNS, kidney & + & $46 \mathrm{GPL}$ & $4 \mathrm{MPL}$ \\
\hline $10(43)$ & M & 47 & PAPS & & & CNS & + & - & - \\
\hline $11(46)$ & M & 55 & Lupus-like & DVT & ACE inhibitor & PVT, heart, kidney, skin & + & High + & - \\
\hline $12(49)$ & $\mathrm{F}$ & 74 & PAPS & $\begin{array}{l}\text { DVT, PE, LR, } \\
\text { skin ulcers }\end{array}$ & & Heart, CNS, kidney, retina & + & $200 \mathrm{GPL}$ & NR \\
\hline $13(62)$ & $\mathrm{F}$ & 48 & PAPS & DVT & Cholectomy, sepsis & Liver, Gl tract, peripheral nerves & NR & Moderate + & Moderate + \\
\hline $14(63)$ & M & 47 & PAPS & $\begin{array}{l}\text { TIA, CVA, } \\
\text { myocardial } \\
\text { infarction }\end{array}$ & Leg ulcer infection & PAT, CNS, kidney, skin & + & + & NR \\
\hline $15(69)$ & $\mathrm{F}$ & 28 & SLE & & Pneumonia & Heart, kidney, skin, GI tract & NR & + & NR \\
\hline $16(72)$ & $\mathrm{F}$ & 42 & SLE & $\begin{array}{l}\text { Fetal loss, } \\
\text { CVA, LR, } \\
\text { thrombocytopenia }\end{array}$ & & $\begin{array}{l}\text { Heart, CNS, kidney, skin, liver, } \\
\text { spleen }\end{array}$ & + & $72 \mathrm{GPL}$ & NR \\
\hline $17(74)$ & $\mathrm{F}$ & 16 & PAPS & & $\begin{array}{l}\text { Upper respiratory } \\
\text { infection }\end{array}$ & $\begin{array}{l}\text { PVT, CNS, skin, peripheral } \\
\text { nerves }\end{array}$ & + & $100 \mathrm{GPL}$ & - \\
\hline $18(76)$ & $\mathrm{F}$ & 21 & SLE & & $\begin{array}{l}\text { Upper respiratory } \\
\text { infection }\end{array}$ & $\begin{array}{l}\text { PVT, heart, CNS, kidney, skin, } \\
\text { transverse myelitis }\end{array}$ & - & $88 \mathrm{GPL}$ & - \\
\hline $19(77)$ & $\mathrm{F}$ & 54 & SLE & & $\begin{array}{l}\text { Cutaneous and } \\
\text { urinary infection, } \\
\text { abdominal surgery }\end{array}$ & $\begin{array}{l}\text { PVT, heart, skin, liver, transverse } \\
\text { myelitis }\end{array}$ & - & - & $96 \mathrm{MPL}$ \\
\hline $20(78)$ & $\mathrm{F}$ & 17 & PAPS & & OC, sun exposure & $\begin{array}{l}\text { PVT, heart, CNS, kidney, skin, } \\
\text { transverse myelitis }\end{array}$ & - & $104 \mathrm{GPL}$ & - \\
\hline $21(82)$ & $\mathrm{F}$ & 26 & SLE & DVT & Post-fetal loss & CNS, kidney, skin & NR & $24 \mathrm{GPL}$ & NR \\
\hline $22(94)$ & M & 18 & SLE & & & Heart, CNS, kidney, skin, pleura & NR & + & NR \\
\hline $23(99)$ & $\mathrm{F}$ & 33 & PAPS & $\begin{array}{l}\text { Fetal loss, } \\
\text { superficial venous } \\
\text { thrombosis }\end{array}$ & $\begin{array}{l}\text { Pregnancy, } \\
\text { caesarean section }\end{array}$ & Heart, CNS, kidney, skin & + & $>100 \mathrm{GPL}$ & - \\
\hline $24(104)$ & $\mathrm{F}$ & 28 & SLE & $\begin{array}{l}\text { DVT, } \\
\text { thrombocytopenia }\end{array}$ & & PVT, heart, CNS, kidney & + & + & - \\
\hline $25(106)$ & $\mathrm{F}$ & 67 & PAPS & & Urinary infection & Heart, CNS, kidney & + & High + & - \\
\hline $26(108)$ & $\mathrm{F}$ & 20 & PAPS & & Throat infection & PVT, CNS, kidney, skin & - & + & - \\
\hline $27(110)$ & $\mathrm{F}$ & 22 & SLE & Fetal loss & HELLP & CNS, kidney, cranial nerve & + & + & + \\
\hline $28(121)$ & $\mathrm{F}$ & 27 & PAPS & DVT, fetal loss & Post-fetal loss & Heart, liver & - & $72 \mathrm{GPL}$ & - \\
\hline $29(125)$ & $\mathrm{F}$ & 39 & Lupus-like & $\begin{array}{l}\text { Fetal death, } \\
\text { amaurosis fugax, } \\
\text { TIA }\end{array}$ & & Heart, CNS, kidney, skin & + & High + & - \\
\hline 30 (127) & $\mathrm{F}$ & 49 & SLE & & $\begin{array}{l}\text { Major abdominal } \\
\text { surgery }\end{array}$ & $\begin{array}{l}\text { PAT, heart, CNS, kidney, skin, } \\
\text { GI tract, pancreas }\end{array}$ & + & $128 \mathrm{GPL}$ & - \\
\hline 31 (132) & M & 39 & & & & $\begin{array}{l}\text { Heart, CNS, kidney, skin, adrenal } \\
\text { glands }\end{array}$ & + & $174 \mathrm{GPL}$ & - \\
\hline $32(134)$ & $\mathrm{F}$ & 21 & PAPS & DVT & Vascular surgery & CNS, kidney, liver & + & High & High + \\
\hline $33(149)$ & $\mathrm{F}$ & 18 & SLE & Thrombocytopenia & $\begin{array}{l}\text { Respiratory } \\
\text { infection }\end{array}$ & $\begin{array}{l}\text { CNS, kidney, spleen, pancreas, } \\
\text { thyroid }\end{array}$ & + & $164 \mathrm{GPL}$ & - \\
\hline $34(158)$ & M & 55 & PAPS & DVT & ACE inhibitor & PVT, heart, kidney, skin & + & - & High + \\
\hline $35(176)$ & $\mathrm{F}$ & 47 & SLE & $\begin{array}{l}\text { LR, } \\
\text { thrombocytopenia }\end{array}$ & $\begin{array}{l}\text { Anticoagulation } \\
\text { withdrawal }\end{array}$ & PAT, CNS, skin, adrenal glands & + & NR & $N R$ \\
\hline 36 (177) & $\mathrm{F}$ & 38 & SLE & $\begin{array}{l}\text { CVA, Budd-Chiari } \\
\text { syndrome, } \\
\text { thrombocytopenia }\end{array}$ & Sepsis & PAT, CNS, skin, adrenal glands & + & Moderate + & High + \\
\hline 37 (178) & $\mathrm{F}$ & 63 & SLE & $\begin{array}{l}\text { Fetal loss, LR, } \\
\text { Renal } \\
\text { microangiopathy, } \\
\text { thrombocytopenia, }\end{array}$ & $\begin{array}{l}\text { Major abdominal } \\
\text { surgery }\end{array}$ & $\begin{array}{l}\text { PAT, CNS, skin, GI tract, adrenal } \\
\text { glands }\end{array}$ & + & Moderate + & High + \\
\hline $38(183)$ & M & 15 & PAPS & & & PVT, liver & + & $44 \mathrm{GPL}$ & $12 \mathrm{MPL}$ \\
\hline $39(184)$ & M & 33 & PAPS & $\begin{array}{l}\text { Livedo reticularis, } \\
\text { skin ulcers }\end{array}$ & & Heart, CNS, kidney, skin & + & $860 \mathrm{GPL}$ & NR \\
\hline $40(185)$ & $\mathrm{F}$ & 52 & PAPS & Fetal loss, CVA & & CNS & - & Moderate + & - \\
\hline 41 (199) & M & 11 & SLE & & & PVT, heart, kidney & + & 36 GPL & - \\
\hline $42(200)$ & $\mathrm{F}$ & 9 & SLE & $\begin{array}{l}\text { LR, digital } \\
\text { ulceration }\end{array}$ & $\begin{array}{l}\text { Lupus flare, urinary } \\
\text { infection }\end{array}$ & CNS, skin & - & $100 \mathrm{GPL}$ & - \\
\hline $43(201)$ & $\mathrm{F}$ & 31 & SLE & & Oestrogens & $\begin{array}{l}\text { Heart, CNS, kidney, liver, } \\
\text { pancreas, myometrium }\end{array}$ & + & + & + \\
\hline $44(204)$ & $\mathrm{F}$ & 38 & SLE & & GI infection & CNS, kidney, skin & + & + & + \\
\hline
\end{tabular}


Table 1 Continued

\begin{tabular}{|c|c|c|c|c|c|c|c|c|c|}
\hline Case $^{*}$ & Sex & $\begin{array}{l}\text { Age } \\
\text { (y) }\end{array}$ & Diagnosis & $\begin{array}{l}\text { Previous APS } \\
\text { manifestations }\end{array}$ & Precipitating factor & $\begin{array}{l}\text { Other organ involvement at the } \\
\text { time of catastrophic APS }\end{array}$ & LA & $\lg G$ aCL & $\lg M a C L$ \\
\hline 45 (207) & $\mathrm{F}$ & 20 & PAPS & & $\mathrm{Gl}$ infection & Kidney, GI tract & + & $72 \mathrm{GPL}$ & - \\
\hline $46(211)$ & $\mathrm{F}$ & 27 & SLE & LR, skin ulcers & Lupus flare & $\begin{array}{l}\text { PVT, CNS, kidney, skin, adrenal } \\
\text { glands }\end{array}$ & + & High + & - \\
\hline $47(213)$ & $\mathrm{F}$ & 27 & SLE & & $\begin{array}{l}\text { Upper respiratory } \\
\text { infection }\end{array}$ & Heart, CNS, kidney, liver & + & Moderate + & - \\
\hline
\end{tabular}

*The numbers in parentheses correspond to the order of the cases in the CAPS registry.

$\mathrm{ACE}$, angiotensin converting enzyme; aCL, anticardiolipin antibodies; APS, antiphospholipid syndrome; CNS, central nervous system; CVA, cerebrovascular accident; DVT, deep venous thrombosis; ERCP, endoscopic retrograde cholangio-pancreatography; $F$, female; GI, gastrointestinal; HELLP, Haemolysis, Elevated Liver Enzymes, and Low Platelets syndrome; LA, lupus anticoagulant; LR, livedo reticularis; M, male; NR, not recorded; OC, oral contraceptives; PAPS, primary APS; SLE, systemic lupus erythematosus; SVC, superior vena cava; PAT, peripheral artery thrombosis; PE, pulmonary embolism; PVT, peripheral venous thrombosis; TIA, transient ischaemic attack; $y$, years.

with mechanically ventilated control patients. These antibodies were directed mainly against anionic phospholipids. However, it is difficult to determine whether the presence of

Table 2 Treatment and outcome of patients with acute respiratory distress syndrome plus catastrophic antiphospholipid syndrome

\begin{tabular}{|c|c|c|}
\hline Case* $^{*}$ & Treatment & Outcome \\
\hline $1(2)$ & $A C, S, C P, P E$ & Recovery \\
\hline $2(3)$ & $A C, S, C P, P E$ & Recovery \\
\hline $3(14)$ & $\mathrm{AC}, \mathrm{S}$ & Recovery \\
\hline $4(16)$ & & Death \\
\hline $5(20)$ & & Death \\
\hline $6(26)$ & $\begin{array}{l}\mathrm{AC}, \mathrm{S}, \mathrm{CP}, \mathrm{PE}, \mathrm{GG} \text {, vincristine, } \\
\text { splenectomy }\end{array}$ & Death \\
\hline 7 (33) & $A C, S, G G$ & Recovery \\
\hline $8(36)$ & $\mathrm{S}, \mathrm{HD}$ & Death \\
\hline $9(41)$ & $A C, S, P E, H D$ & Recovery \\
\hline $10(43)$ & $A C$ & Recovery \\
\hline $11(46)$ & AC, fibrinolytics & Recovery \\
\hline $12(49)$ & $A C, S, G G$ & Recovery \\
\hline $13(62)$ & $A C, S$ & Recovery \\
\hline $14(63)$ & $A C, S, G G$ & Recovery \\
\hline $15(69)$ & & Death \\
\hline $16(72)$ & $A C, S, C P, P E$ & Death \\
\hline $17(74)$ & $A C, S$ & Recovery \\
\hline $18(76)$ & $A C, S, C P$ & Death \\
\hline 19 (77) & $A C, S, C P$ & Recovery \\
\hline $20(78)$ & $\mathrm{AC}, \mathrm{S}, \mathrm{CP}$ & Death \\
\hline $21(82)$ & $A C, S, C P$ & Recovery \\
\hline $22(94)$ & $\mathrm{S}, \mathrm{CP}, \mathrm{PE}$ & Death \\
\hline $23(99)$ & $A C, S, G G$ & Death \\
\hline $24(104)$ & $A C, S, G G$ & Death \\
\hline $25(106)$ & $A C, S$ & Death \\
\hline $26(108)$ & $A C, S, C P, G G$ & Recovery \\
\hline $27(110)$ & $A C, S, G G$ & Recovery \\
\hline $28(121)$ & $A C, S$ & Recovery \\
\hline $29(125)$ & $A C, S, C P, G G$, prostacyclin & Recovery. \\
\hline 30 (127) & $A C, S, C P, P E, H D$ & Death \\
\hline 31 (132) & $A C, S, P E, G G$ & Recovery \\
\hline 32 (134) & $A C, S, P E, G G, H D$ & Recovery \\
\hline $33(149)$ & $A C, S, C P, G G, H D$ & Death \\
\hline $34(158)$ & $A C$, aspirin & Recovery \\
\hline $35(176)$ & $A C, S, C P, G G$ & Death \\
\hline $36(177)$ & $A C, S, C P, G G$ & Death \\
\hline 37 (178) & $A C, S, G G$ & Death \\
\hline $38(183)$ & $A C, S, G G$ & Recovery \\
\hline 39 (184) & $A C$ & Recovery \\
\hline $40(185)$ & $A C, S$ & Recovery \\
\hline 41 (199) & $A C, S, C P, P E, G G$ & Recovery \\
\hline $42(200)$ & $A C, S, C P, P E, G G$ & Recovery \\
\hline $43(201)$ & $A C, S, P E$ & Recovery \\
\hline $44(204)$ & $A C, S, P E, H D$ & Death \\
\hline $45(207)$ & $A C, S, G G$ & Recovery \\
\hline $46(211)$ & $A C, C P, P E, G G$ & Recovery \\
\hline $47(213)$ & $A C, S, P E, G G, H D$ & Death \\
\hline
\end{tabular}

*The numbers in parentheses correspond to the order of the cases in the CAPS registry.

$A C$, anticoagulation; $C P$, cyclophosphamide; $G G$, intravenous gamma globulin; $\mathrm{HD}$, haemodialysis; $\mathrm{PE}$, plasma exchange; $\mathrm{S}$, steroids S, steroids. these autoantibodies was associated with modifications of the lipid composition of the surfactant or whether they were produced in response to damage to the alveolar or other cell membranes. Furthermore, these antibodies may be produced locally or be provided from plasma following the increased capillary-alveolar permeability present in ARDS. The same group showed that the aPL detected in the BALF of a patient developing ARDS during catastrophic APS did not have the same specificity towards the different phospholipids as aPL in the serum. ${ }^{26}$ This supports the hypothesis of local production of aPL. Additionally, a quantitative as well as a qualitative deficiency of surfactant phospholipids was also observed. ${ }^{26}$ The investigators suggested that antibodies directed against surfactant phospholipids could cause surfactant abnormalities and a resulting inflammatory reaction. Unfortunately, so far there are no experimental data on a possible effect of aPL on the function of the surfactant.

The systemic inflammatory response syndrome (SIRS) secondary to cytokine activation could be another pathogenic mechanism of indirect injury in the ARDS associated to catastrophic APS. A complex network of cytokines initiate and amplify the inflammatory response in ARDS. The extensive tissue damage caused by catastrophic APS results in the liberation of excessive amounts of cytokines. Some of the major clinical manifestations of catastrophic APS resulting from multiple small vessel occlusive disease and consequent tissue necrosis (that is, ARDS and decreased cardiac function) may be directly attributable to SIRS. ${ }^{27}$ In support of this is the recent report of a study in which the cytokine levels of a patient with catastrophic APS were evaluated. The study showed that vascular endothelial cell injury might play a major role in the pathogenesis of catastrophic APS..$^{28}$ The cytokines involved in ARDS include tumour necrosis factor $\alpha$, interleukin 1 (IL1), IL6, ${ }^{29}$ and macrophage migration inhibitory factor. ${ }^{30}$ These have been found to be increased in both sera and BALF of ARDS patients, and they are responsible not only for ARDS but also for the cerebral oedema which may be a factor in the initial confusion and deterioration of consciousness seen in patients with SIRS, as well as the myocardial dysfunction encountered.$^{30}$ There appears to be a massive influx of neutrophils into the damaged tissues. The concentration of potent neutrophil chemoattractants, such as IL8, is also increased in BALF. ${ }^{31}$ Additionally, IL18-a proinflammatory cytokine which induces the production of several other cytokinesincluding interferon $\gamma$-and enhances $\mathrm{T}$ cell and natural killer cell toxicity as well as neutrophil migration and degranulation. It may also be implicated in acute lung inflammation by increasing neutrophil migration and lung vascular permeability. This cytokine may also be implicated in the pathogenesis of ARDS. ${ }^{29}$

Finally, pathological examination of lung specimens from patients with ARDS in catastrophic APS showed extensive 
small vessel thromboses, intra-alveolar haemorrhage, and hyaline membrane formation. ${ }^{32}$ Interestingly, in our study, the main pathological finding was non-inflammatory thrombotic microangiopathy, present in $70 \%$ of the patients with lung specimens. This may produce an increase in vascular permeability, surfactant deficiency, and intra-alveolar inflammation. It is another probable pathogenic mechanism of ARDS and is closely linked to activation of inflammation and coagulation, which is characterised by fibrin deposition in the pulmonary parenchyma, vasculature, and air spaces. This procoagulant state is tissue factor dependent and is associated with increased elaboration of inflammatory cytokines. $^{33}$

\section{Conclusion}

ARDS is the dominant pulmonary manifestation of catastrophic APS. Our study shows that catastrophic APS is a major risk factor for the development of ARDS. The presence of ARDS in the context of an APS makes it necessary to rule out the catastrophic variant of this syndrome.

\section{Authors' affiliations \\ S Bucciarelli, G Espinosa, R Cervera, G Claver, J A Gómez-Puerta, M Ramos-Casals, M Ingelmo, Department of Autoimmune Diseases, Institut Clínic de Medicina i Dermatologia, Hospital Clínic, Institut $\mathrm{d}^{\prime}$ Investigacions Biomèdiques August Pi i Sunyer, Barcelona, Catalonia, Spain \\ R A Asherson, Rheumatic Diseases Unit, Department of Medicine, University of Cape Town Faculty of Health Sciences and Groote Schuur Hospital, Cape Town, South Africa \\ *The members of the Catastrophic Antiphospholipid Syndrome Registry Project Group are listed in the appendix.}

\section{APPENDIX}

\section{THE CATASTROPHIC ANTIPHOSPHOLIPID SYNDROME REGISTRY PROJECT GROUP}

The members of the Catastrophic APS Registry Project Group who contributed to this study are as follows:

Mary-Carmen Amigo, Rheumatology Department, Instituto Nacional de Cardiología, Ignacio Chávez, Mexico City, Mexico; Leonor Barile-Fabris, Rheumatology Department, Hospital de Especialidades, Centro Medico la Raza IMSS, Mexico City, Mexico; Jean-Jacques Boffa, Deparment of Nephrology, Hôpital Tenon, Paris, France; Marie-Claire Boffa, Hôpital Pitié-Salpêtrière, Paris, France; Joab Chapman, Neuroimmunology Service, Tel Aviv Sourasky Medical Centre, Tel Aviv, Israel; Christopher Davidson, Department of Cardiology, Royal Sussex Hospital, Brighton, UK; Alex E Denes, Division of Oncology, Department of Medicine, Washington University School of Medicine, St Louis, Missouri, USA; Ronald H W M Derksen, Department of Rheumatology and Clinical Immunology, University Medical Centre, Utrecht, Netherlands; J F Diaz Coto, Caja Costarricense del Seguro Social, San Jose, Costa Rica; Patrick Disdier, Service de Medecine Interne, Centre Hospitalier Universitaire Timone, Marseille, France; Rita M Egan, Department of Medicine, University of Kentucky Medical Center, Lexington, Kentucky, USA; M Ehrenfeld, Chaim Sheba Medical Centre and Tel-Aviv University, TelHashomer, Israel; R Enriquez, Nephrology Section, Hospital General de Elx, Spain; Doruk Erkan, Hospital for Special Surgery, New York, USA; Fernanfa Falcini, Department of Paediatrics, University of Florence, Italy; Leslie S Fang, Renal Associates, Massachusetts General Hospital and Harvard Medical School, Boston, Massachusetts, USA; Mario GarcíaCarrasco, Benemérita Universidad Autónoma de Puebla, Puebla, Mexico; John T Grandone, Neenah, Wisconsin,
USA; Anagha Gurjal, Division of Hematology/Oncology, Barbara Ann Karmanos Cancer Institute, Detroit, Michigan, USA; Gilles Hayem, Department of Rheumatology, CHU Bichat-Claude-Bernard, Paris, France; Graham R V Hughes, Lupus Research Unit, The Rayne Institute, St Thomas' Hospital, London, UK; Sohail Inam, Riyadh Armed Forces Hospital Riyadh, Saudi Arabia; K Shashi Kant, Department of Internal Medicine, University of Cincinnati College of Medicine, Cincinnati, Ohio, USA; Munther A Khamashta, Lupus Research Unit, The Rayne Institute, St Thomas' Hospital, London, UK; Craig S Kitchens, Department of Medicine, University of Florida, Gainesville, USA; Michael J Kupferminc, Department of Obstetrics and Gynaecology, Lis Maternity Hospital, Tel Aviv University, Tel Aviv, Israel; Gabriela de Larrañaga, Hospital Muñiz, Buenos Aires, Argentina; Roger A Levy, Department of Rheumatology, Faculdade de Ciencias Medicas, Universidade do Estado do Rio de Janeiro, Rio de Janeiro, Brazil; Michael D Lockshin, Hospital for Special Surgery, New York, USA; Siu Fai Lui, Department of Medicine, Prince of Wales Hospital and Chinese University of Hong Kong, Shatin, Hong Kong; Peter J Maddison, Gwynedd Rheumatology Service, Ysbyty Gwynedd, Bangor, UK; Yoseph A Mekori, Department of Medicine, Meir Hospital, Kfar Saba, Israel; Takako Miyamae, Department of Paediatrics, Yokohama City University School of Medicine, Yokohama, Japan; John Moore, Department of Haematology, St Vincent's Hospital, Sydney, Australia; Haralampos M Moutsopoulos, Department of Pathophysiology, Medical School, National University of Athens, Athens, Greece; Francisco J Muñoz-Rodríguez, Department of Autoimmune Diseases, Hospital Clinic, Barcelona, Catalonia, Spain; Jacek Musial, Jagiellonian University School of Medicine, Krakow, Poland; Ayako Nakajima, Institute of Rheumatology, Tokyo Women's Medical University, Tokyo, Japan; Michael C Neuwelt, Medical Service, VA Palo Alto Health Care System, California, USA; Ann Parke, Department of Internal Medicine, Division of Rheumatic Diseases, University of Connecticut Health Center, Connecticut, USA; Jean-Charles Piette, Hôpital Pitié-Salpêtrière, Paris, France; Sonja Praprotnik, Univerisity Clinical Centre, Department of Rheumatology, Ljubljana, Slovenia; Bernardino Roca, Department of Internal Medicine, Hospital General de Castelló, Castelló, Spain; Jorge Rojas-Rodriguez, Department of Rheumatology, Specialties Hospital, Manuel Avila Camacho National Medical Centre, Puebla, Mexico; R Roldan, Rheumatology Department, Hospital Reina Sofia, Cordoba, Spain; Allen D Sawitzke, Division of Rheumatology, Department of Internal Medicine, University of Utah School of Medicine, Salt Lake City, Utah, USA; Cees G Schaar, Department of Haematology, Leiden University Medical Centre, Leiden, Netherlands; Yehuda Shoenfeld, ChaimSheba Medical Centre, Tel-Hashomer, Israel; Alenka ŠipekDolnicar, Department of Rheumatology, University Medical Centre, Ljubljana, Slovenia; Alex C Spyropoulos, Clinical Thrombosis Centre, Albuquerque, New Mexico, USA; Renato Sinico, Nephrology and Dialysis Unit and Centre of Clinical Immunology and Rheumatology, San Carlo Borromeo Hospital, Milan, Italy; Ljudmila Stojanovich, ClinicalHospital Centre "Bezhanijska Kosa", Belgrade, Yugoslavia; Daryl Tan, Singapore General Hospital, Singapore; Maria Tektonidou, Department of Pathophysiology, Medical School, National University of Athens, Athens, Greece; Carlos Vasconcelos, Hospital General de San Antonio, Porto, Portugal; Marcos Paulo Veloso, Hospital Universitario Clementino Fraga Filho, Rio de Janeiro, Brazil; Margaret Wislowska, Outpatients Department of Rheumatology, Central Clinical Hospital, Warsaw, Poland. 


\section{REFERENCES}

1 Ware LB, Matthay MA. The acute respiratory distress syndrome. N Engl J Med 2000;342: 1334-9.

2 Wyncoll DLA, Evans TW. Acute respiratory distress syndrome. Lancet 1999;354:497-501.

3 Andonopoulos AP. Adult respiratory distress syndrome: an unrecognized premortem event in systemic lupus erythematosus. $\mathrm{Br} J$ Rheumatol 1992;31:346-8

4 Asherson RA, Ridley M, Fletcher CD, Hughes GRV. Systemic lupus erythematosus, pulmonary hypertension and adult respiratory distress syndrome (ARDS). Clin Exp Rheumatol 1988:6:301-4.

5 Domingo-Pedrol P, Rodriguez de la Serna A, Mancebo-Cortes J, SanchezSegura JM. Adult respiratory distress syndrome caused by acute systemic lupus erythematosus. Eur J Resp Dis 1985;67:141-4

$6 \mathrm{Kim}$ WU, Kim SI, Yoo WH, Park JH, Min JK, Kim SC, et al. Adult respiratory distress syndrome in systemic lupus erythematosus: causes and prognostic factors: a single center, retrospective study. Lupus 1999;8:552-7.

7 Marino CT, Pertschuck LP. Pulmonary hemorrhage in systemic lupus erythematosus. Arch Intern Med 1981;141:201-3.

8 Asherson RA. The catastrophic antiphospholipid syndrome. J Rheumatol 1992: 19:508-12.

9 Piette JC, Cervera R, Levy R, Nasonov EL, Triplett DA, Shoenfeld Y. The catastrophic antiphospholipid syndrome - Asherson's syndrome. Ann Med Intern 2003;154:95-6.

10 Asherson RA, Cervera R, de Groot PR, Erkan D, Boffa M-C, Piette J-C, et al. Catastrophic antiphospholipid syndrome: international consensus statement on classification criteria and treatment guidelines. Lupus 2003;12:530-4.

11 Asherson RA, Cervera R, Piette JC, Font J, Lie JT, Borcoglu A, et al. Catastrophic antibody syndrome. Clinical and laboratory features of 50 patients. Medicine (Baltimore) 1998;77:195-207.

12 Asherson RA, Cervera R, Piette JC, Shoenfeld Y, Espinosa G, Petri MA, et al. Catastrophic antiphospholipid syndrome: clues to the pathogenesis from a series of 80 patients. Medicine (Baltimore) 2001;80:355-76

13 Cervera R, Gomez-Puerta JA, Espinosa G, Font J, De la Red G, Gil V, et al. CAPS Registry: a review of 200 cases from the International Registry of patients with catastrophic antiphospholipid syndrome (CAPS) [abstract]. Ann Rheum Dis 2003;62(suppl 1):88.

14 Bernard GR, Artigas A, Brigham KL, Carlet J, Falke K, Hudson L, et al. The American-European Consensus Conference on ARDS: definitions, mechanisms, relevant outcomes, and clinical trial coordination. Am J Respir Crit Care Med 1994; 149:818-24.

15 Murray JF, Matthay MA, Luce JM, Flick MR. An expanded definition of the adult respiratory distress syndrome. Am Rev Respir Dis 1988;138:720-3.

16 Hochberg MC. Updating the American College of Rheumatology revised criteria for the classification of systemic lupus erythematosus [letter]. Arthritis Rheum 1997; 40:1725

17 Wilson WA, Gharavi AE, Koike T, Lockshin MD, Branch DW, Piette J-C, et al International consensus statement on preliminary classification criteria for definite antiphospholipid syndrome: report of an international workshop. Arthritis Rheum 1999;42:1309-11.
18 Gattionini L, Pelosi P, Suter PM, Pedoto A, Vercesi P, Lissoni A. Acute respiratory distress syndrome caused by pulmonary and extrapulmonary disease: different syndromes? Am J Resp Crit Care Med 1998;158:3-11.

19 Hudson LD, Milberg JA, Anardi D, Maunder RJ. Clinical risks for development of the acute respiratory distress syndrome. Am J Respir Care Med 1995; 151:293-301

20 Carron PL, Surcin S, Plane P, Balvay P, Caps T, Belle F, et al. Adult-onset Still's disease: a rare cause of acute respiratory distress. Rev Med Interne 2000;21:1133-4.

21 Hirohata S, Kamoshita H, Taketani T, Maeda S. Adult Still's disease complicated with adult respiratory distress syndrome. Arch Intern Med 1986;146:2409-10.

22 Wiedermann FJ, Mayr A, Schobersberger W, Knotzer H, Sepp N, Rieger M, et al. Acute respiratory failure associated with catastrophic antiphospholipid syndrome. J Intern Med 2000;247:723-30.

23 Pugin J, Verghese G, Vidmer M-C, Matthay MA. The alveolar space is the site of intense inflammatory and profibrotic reactions in the early phase of acute respiratory distress syndrome. Crit Care Med 1999;27:304-12.

24 Holter JF, Weiland JE, Pacht ER, Gadek JE, Davis WB. Protein permeability in the adult respiratory distress syndrome: loss of size selectivity of the alveolar epithelium. J Clin Invest 1986;78:1513-22.

25 Maneta-Peyret L, Kitsiouli E, Lekka M, Nakos G, Cassagne C. Autoantibodies to lipids in bronchoalveolar fluid of patients with acute respiratory distress syndrome. Crit Care 2001;29:1950-4.

26 Nakos G, Kitsiouli E, Maneta-Peyret L, Cassagne C, Tsianos E, Lekka M. The characteristics of bronchoalveolar lavage from a patient with antiphospholipid syndrome who develop acute respiratory distress syndrome. Clin Rheumatol 2001;20:91-7.

27 Belmont HM, Abramson SB, Lie JT. Pathology and pathogenesis of vascular injury in systemic lupus erythematosus: interactions of inflammatory cells and activated endothelium. Arthritis Rheum 1996;39:9-22.

28 Burcoglu-O'ral A, Erkan D, Asherson RA. Treatment of catastrophic antiphospholipid syndrome (CAPS) with defibrotide, a proposed vascular endothelial cell modulator. J Rheumatol 2002;29:2006-11.

29 Suter PM, Suter S, Giradin E, Roux-Lombard P, Grau GE, Dayer JM. High bronchoalveolar levels of tumour necrosis factor and its inhibitors, interleukin1 , interferon and elastase, in patients with adult respiratory distress syndrome after trauma, shock or sepsis. Am Rev Resp Dis 1992;145:1016-22.

30 Donnelly SC, Haslett C, Reid PJ, Grant TS, Wallace WA, Metz CN, et al. Regulatory role of macrophage migration inhibitory factor in acute respiratory distress syndrome. Nat Med 1997;3:320-3.

31 Chollet-Martin S, Montravers P, Gibert C, Elbim C, Desmonts JM, Fagon JY, et al. High levels of interleukin-8 in the blood and alveolar spaces of patients with pneumonia and adult respiratory distress syndrome. Infect Immun 1993;61:4553-9.

32 Espinosa G, Cervera R, Font J, Asherson RA. The lung in the antiphospholipid syndrome. Ann Rheum Dis 2002;61:195-8.

33 Welty-Wolf KE, Caraway MS, Ortel TL, Piantadosi CA. Coagulation and inflammation in acute lung injury. Thromb Haemost 2002;88:17-25. 